\title{
Досвід використання фототерапії при лікуванні атипових форм червоного
} плоского лишаю

\author{
М.М. Чемерис, А.А. Дехтярчук \\ Медичний центр «Новодерм», Львів, Україна
}

Анотація. Червоний плоский лишай - одне з найпоширеніших захворювань у дерматології. За останні десятиліття зросла захворюваність на цю патологію. Одним із високоефективних методів лікування на сьогодні $\epsilon$ використання фототерапії в комплексному лікуванні цього захворювання.

Ключові слова: фототерапія, хронічні дерматози, червоний плоский лишай, лікування атипових форм червоного плоского лишаю.

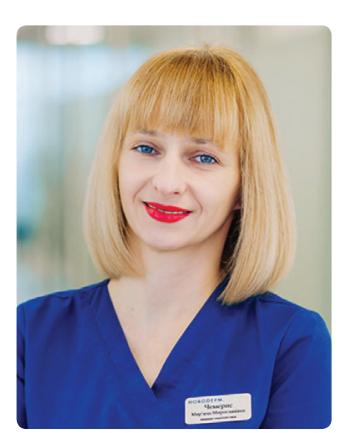

М.М. Чемерис

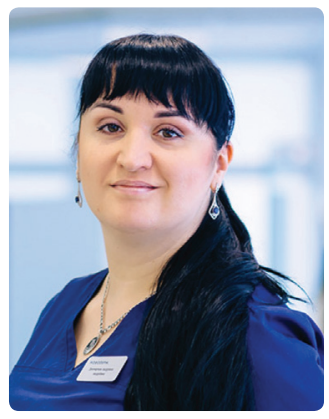

А.А. Дехтярчук

\section{Вступ}

На сьогодні однією з актуальних проблем в дерматології $\epsilon$ лікування хронічних дерматозів, зокрема червоного плоского лишаю (ЧПЛ).

чПЛ - хронічне рецидивуюче папуло-сквамозне захворювання шкіри, що характеризується появою характерних дрібних плоских дискретно розташованих папул фіолетового кольору з полігональними обрисами, які можуть зливатися в щільні бляшки з лусочками на поверхні, часто супроводжуватися ураженням слизової оболонки порожнини рота або геніталій [1-3].

Протягом останніх років зростають рівень захворюваності та поширеність ЧПЛ, частка атипових і тяжких форм з резистентністю до лікування та зменшенням тривалості періоду ремісії.

Етіологія захворювання невідома. У 10\% пацієнтів позитивний сімейний анамнез. Провокуючі фактори виникнення ЧПЛ наступні:

- загострення загальносоматичної патології;

- несановані вогнища інфекції (хронічний тонзиліт, гайморит тощо);

- інфекційні захворювання (зокрема вірусний гепатит В і C);

- психоемоційні навантаження.

Enідеміологія. За даними різних авторів, частка хворих на зазначений дерматоз становить 0,8-2,7\% усіх захворювань шкіри і 7-10\% захворювань слизової оболонки порожнини рота. Зазвичай захворювання відмічають у віці 30-60 років, жінки хворіють частіше $[4,5]$.

За останні роки підвищилася частота рецидивів та кількості хворих з атрофічною, верукозною формами. Згідно з даними вітчизняних та зарубіжних досліджень переродження ЧПЛ стало приводом для віднесення його до преканкрозних захворювань з частотою малігнізації 10-12\% [4, 6, 7], особливо при локалізації вогнищ на слизовій оболонці рота та зовнішніх статевих органах (ризик виникнення лейкоплакії та плоскоклітинної карциноми).

Клінічна картина. Розрізняють наступні клінічні форми ЧПЛ:

- папульозний;

- гіпертрофічний (бородавчастий, верукозний);

- фолікулярний;

- атрофічний;

- ЧПЛ нігтів;

- ЧпЛ слизових оболонок (підвищений ризик розвитку плоскоклітинної карциноми у випадку тривалої персистенції захворювання на слизових оболонках);

- ЧпЛ волосистої частини голови (рубцева алопеція, lichen ruber planus).

Елемент висипу: рожево-червона полігональна папула з ліловим відтінком, боковим полиском. Папули іноді схильні до злиття з утворенням бляшок, гіпертрофічних (верукозних) розростань. При нанесенні рідини або олії на поверхню елемента візуалізується сітка Уікхема (мереживний малюнок тоненьких білих химерних ліній). На слизовій оболонці (рота, геніталій) прояви у вигляді білесуватих, мереживних, мацерованих папул.

Локалізація морфологічних елементів: згинальні поверхні зап'ястків, нижньої $1 / 3$ гомілок, проєкція гомілково-ступневого суглоба, ротова порожнина, рідше - дисемінований процес на шкірі. Висип супроводжується свербежем різного ступеня інтенсивності, частіше свербіж нападоподібний та виснажливий. Нові вогнища можуть з'являтися в місцях травматизації шкіри (позитивна ізоморфна реакція Кебнера).

Діагноз встановлюється на підставі клінічних ознак і підтверджується за допомогою біопсії шкіри. Гістологічна картина: гіперкератоз, скупчення мононуклеарів в пограничній дермоепідермальній зоні.

При атипових формах для верифікації діагнозу частіше виникає потреба у проведенні біопсії елементів висипу з наступним гістологічним дослідженням [2].

Диференційну діагностику проводять з таким захворюваннями, як:

- псоріаз (зливні бляшки зі сріблясто-білим лущенням, інфільтрацією на розгинальних поверхнях кінцівок, відсутність ураження слизових оболонок, позитивна тріада Ауспіца);

- екзема (схильність до мікровезикуляції, еритема, кірко-лусочки на поверхні висипу, локалізація різноманітна, алергологічний анамнез часто обтяжений);

- дискоїдний вовчак (при проявах на волосистій частині голови). При дискоїдному вовчаку - вогнища інфільтрації, рубцевої атрофії, позитивний симптом Беньє - Мещерського, симптом «дамського каблучка»);

- лейкоплакія, кандидоз, пухирчатка. При лейкоплакії - чіткий контур вогнища ураження, давність існування захворювання, цитологічне дослідження для верифікації діагнозу. При кандидозі - бактеріальний посів з вогнищ на наявність Candida albicans. При пухирчатці - болючі ерозії в ротовій порожнині з/без проявів на шкірі у вигляді міхурів, мазоквідбиток на клітини Тцанка, визначення антитіл до десмоглеїну для підтвердження діагнозу;

- вогнищевий/обмежений нейродерміт (інтенсивний свербіж, наявність ліхеніфікації, екскоріації, лущення);

- туберкульоз шкіри (бородавчастий). Переважна локалізація на тильній поверхні кистей і пальців рук, наявність трьох зон в осередку ураження (центральної - зроговілої, бородавчастої, середньої - інфільтрованої, синюшно-червоного кольору, і периферичної - більш яскравого червоного забарвлення і рубцювання; 
- пруріго (свербець). Висипа зазвичай нечисленний, більш великий, щільний, має напівкулясту, овальну форму. Поверхня його часто покрита геморагічними кірочками. Елементи на слизовій оболонці відсутні;

- кільцеподібна гранульома. Локалізація висипу - тильна поверхня кистей, висип у вигляді папул від тілесного до рожево-червоного кольору, що зливаються у вогнища кільцеподібної форми, папули без пупкоподібного втиснення і блиску, фіолетового відтінку і не супроводжуються свербежем;

- склероатрофічний ліхен. Невеликі склероатрофічні осередки білувато-сіруватого кольору, іноді з перламутровим блиском, восковою поверхнею, фолікулярним кератозом. Атрофічні зміни найбільш виражені при локалізації в ділянці вульви, значно ширші, ніж при ЧПЛ. У їхній зоні можуть утворитися міхури з прозорим або геморагічним вмістом. Свербежу при цьому зазвичай не виникає $[3,6,8]$.

При ЧПЛ найчастіше уражується шкіра, хоча у 3,0-26\% випадків відмічають ізольоване ураження слизової оболонки порожнини рота. Можуть виникати ураження піхви, сечового міхура і сечовидільного каналу, прямої кишки, шлунково-кишкового тракту. У 1-13\% хворих відмічають ізольоване ураження нігтьових пластин, частка якого протягом останніх років значно зросла $[3,5,9]$.

Для лікування хворих на ЧПЛ у якості базисної терапії призначають системні глюкокортикостероїди (ГКС) у поєднанні з похідними 4-амінохіноліну (гідроксихлорохін, хлорохін). При гострому і поширеному процесі проводять системну ГКСтерапію в середніх терапевтичних дозах (30-60 мг за преднізолоном) або ГКС пролонгованої дії бетаметазоном дипропіонатом $[1,5]$. Призначають імунотропну терапію, у тому числі із застосуванням екзогенних інтерферонів та інтерфероногенів. При поширеному висипі, гострому перебігу захворювання, виявленні у хворих осередків хронічної інфекції застосовують антибіотикотерапію. У гострий період за наявності інтенсивного свербежу показані блокатори $\mathrm{H}_{1}$-гістамінових рецепторів, антисеротонінові препарати [2-4]. Ефективним також $\epsilon$ призначення комплексу вітамінів-антиоксидантів, що складається з а-токоферолу, $\beta$-каротину, аскорбінової кислоти $[1,5,8]$. Хворим із генералізованим висипом доцільним $\epsilon$ призначення нікотинової кислоти в поєднанні з метилксантинами протягом 3-4 тиж та рутину, рибофлавіну [2, 6, 8].

Зовнішні методи лікування чпЛ передбачають застосування топічних ГКС, розчинів з ментолом, анестезином, антигістамінові засоби, що призначають при інтенсивному свербежу. При локалізації осередків ураження на слизовій оболонці рота, статевих органів доцільні ванночки або полоскання розчином шавлії, ромашки та іншими рослинними засобами [5].

Одним із сучасних і безпечних методів немедикаментозної терапії $\epsilon$ використання фототерапії [1, 3, 6]. Фототерапія, або світлолікування, відома ще з давніх часів і передбачає використання ультрафіолету (УФ) певного спектру в лікувальних цілях. Це безпечний і надійний метод, який ефективно допомагає більшос- ті пацієнтів при таких хронічних рецидивуючих дерматозах, як псоріаз, вітиліго, атопічний дерматит, екзема, ЧПЛ тощо.

УФ-випромінювання стимулює ряд обмінних процесів, чинить місцеву імуномодулючу дію: протизапальну і загальнозміцнювальну, а також гальмує прискорений поділ клітин рогового шару епідермісу. Але спектральна характеристика сонячного світла дуже непостійна і залежить від сезону, часу дня, географічної локалізації, кліматичного статусу та ряду інших факторів. Тому часто використовувати сонячні промені з лікувальною метою в сучасних умовах не $є$ можливим. Крім того, сонячне випромінювання несе в собі не тільки корисну «лікувальну» частину УФ-спектра, а й інфрачервоне випромінювання, яке викликає перегрівання. Тому на початку минулого століття вченими здійснені спроби створення штучних джерел світла, які можна було 6 використовувати для опромінення пацієнтів у медичних цілях для фототерапії.

На початку 1980-х років помічено, що сприятливий ефект УФ В (Ultraviolet B - UVB) в основному пов'язаний з довжинами хвиль 295-313 нм, а діапазон 310-313 нм має найкращий профіль безпеки. Отже, розроблена лампа, що випромінює УФ-опромінення з піком при 311-312 нм, відомим як вузькосмуговий UVB (Narrow Band UVB - NB UVB), що виключає коротші, фотобіологічно більш небезпечні довжини хвиль. Кілька досліджень показали, що NB UVB інгібує проліферацію і здатний індукувати апоптоз в людських кератиноцитах як в пробірці, так і в природних умовах. Інгібування росту клітин під час повторного лікування NB UVB також може бути пов'язане з опосередкованими GATA3 шляхами. GATA3 - фактор транскрипції з двома мотивами цинкового пальця, який зв'язується з 6-нуклеотидною послідовністю (A/T) GATA (A/G). Це має важливе значення для правильного формування епідермального бар'єру, регуляції епідермальної диференціації та десквамації. Останній ефект опосередковується активацією калікреїну-1. Показано, що рівень GATA3 знижений у пацієнтів із псоріазом, хронічним запальним захворюванням шкіри (в тому числі ЧПЛ), що характеризується високим рівнем проліферації кератиноцитів (гістологічно - розвиток гіпер- і паракератозу, акантозу).

NB UVB здатний викликати апоптоз в клітинах епідермісу подібним чином, як це робить широкосмуговий UVB. Опромінення NB UVB також провокує значну перебудову цитоскелета клітин, викликаючи витончення мікрофіламентів та їх перерозподіл по периферії клітини. Порушення клітинних мембран культивованих клітин при NB UVB-опроміненні супроводжувалося значними змінами вмісту клітинних ліпідів. NB UVB-опромінення призводить до збільшення виробництва керамідів, тобто видів ліпідів, які вважаються перетворювачами сигналу для різних клітинних стресових факторів, включаючи активні форми кисню, цитокіни, вплив хіміотерапевтичних засобів, опромінення або екзогенні ліпополісахариди. Підвищений рівень кераміду провокує зупинку клітинного циклу та/або апоптоз у різних типів клітин з надмірним поділом (що лежить в основі патогенезу розвитку більшості хронічних папуло-сквамозних дерматозів).

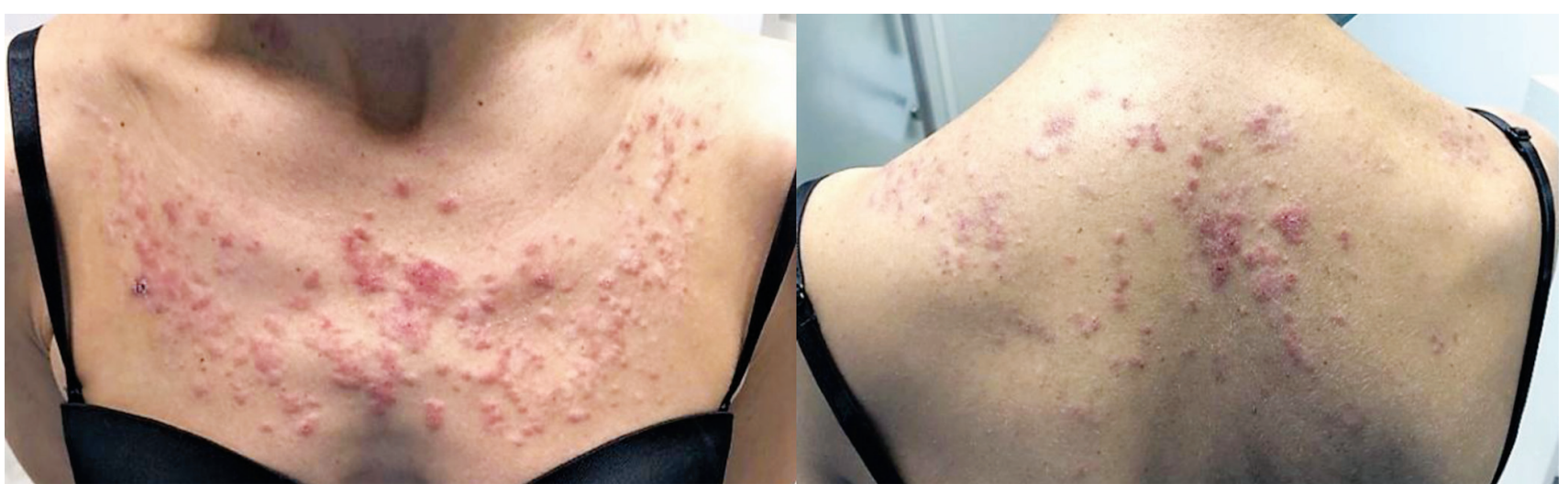


Рисунок 2 Клінічна картина після лікування

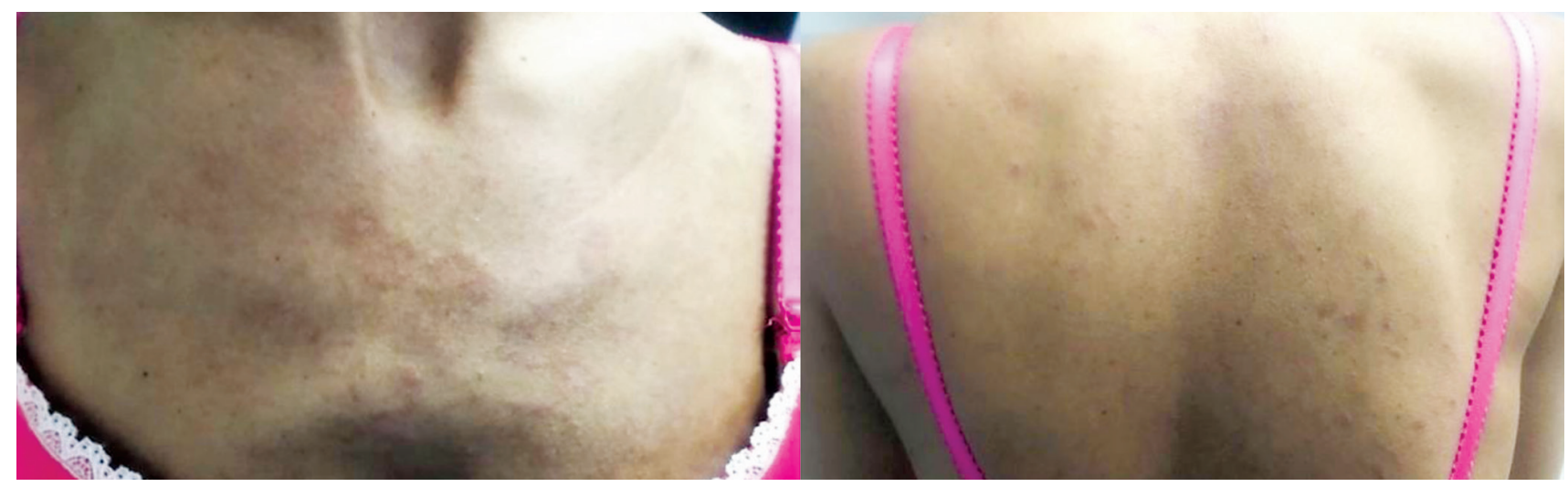

\section{Клінічний випадок}

Пацієнтка М., 35 років. Скарги на висип на шкірі тулуба верхніх кінцівок, інтенсивний свербіж (рис. 1). Висип, за словами пацієнтки, турбує $>10$ років, має постійний поширений характер. Незначне покращення стану шкіри відмічала у літній період.

Спадковий та алергологічний анамнез не обтяжений, соматично здорова.

Загальний аналіз крові: гемоглобін 132 г/л, еритроцити $4,5 \cdot 10^{12} /$ л, лейкоцити $5 \cdot 10^{9} /$ л, тромбоцити $256 \cdot 10^{9} /$ л, еозинофіли $1 \%$, лімфоцити $42 \%$, моноцити $1 \%$, базофіли 0\%, сегментоядерні нейтрофіли 48\%, швидкість осідання еритроцитів 10 мм/год.

Біохімічний аналіз крові: аспартатамінотрансфераза 18 Од/л, аланінамінотрансфераза 18 Од/л, гамма-глутамілтрансфераза 12 Од/л, білірубін 7,2 мкмоль/л, загальний білок 72 г/л, сечовина 4,2 ммоль/л, креатинін 67 мкмоль/л.

Ультразвукове дослідження органів черевної порожнини та заочеревинного простору, щитоподібної залози: без патології.

Status localis: на шкірі декольте, спини, живота наявні множинні полігональні папули рожево-багряного кольору, які місцями зливаються у дрібні інфільтровані бляшки, з боковим блиском та незначним пупковидним западанням на поверхні. На зовнішньолатеральній поверхні плечей — поодинокі тілесні фолікулярні папули. На слизовій оболонці щік — лінійні мацеровані папули у вигляді «мережива».

Пацієнтці призначено доксициклін 100 мг 2 рази на добу протягом 7 днів та топічно мазь мометазону 1 раз на добу протягом 7 днів. Через 1 тиж приєднано курс фототерапії (UVB 311 нм) за схемою 3 рази на тиждень в дозі 300 кДж+50, 15 сеансів. Скориговано топічний догляд, додано емолієнти (Фізіогель). У результаті проведеного лікування висип регресував, папули зменшилися і посвітлішали), свербіж не турбував, нового висипу не виявлено (рис. 2).

\section{Висновок}

Використання фототерапії сьогодні $\epsilon$ одним із високоефективних та безпечних методів у комплексному лікуванні хронічних дерматозів, зокрема атипових форм ЧПЛ. Метод $\epsilon$ без-

\section{Відомості про авторів:}

Чемерис Мар'яна Мирославівна — кандидат медичних наук, дерматовенеролог, трихолог вищої кваліфікаційної категорії, Медичний центр «Новодерм», Львів, Україна.

Дехтярчук Андріана Андріївна - дерматовенеролог першої кваліфікаційної категорії, дерматоонколог, Медичний центр «Новодерм», Львів, Україна.

\section{Адреса для кореспонденції:}

Дехтярчук Андріана Андріївна

79026, Львів, вул. Академіка Андрія Сахарова, 82

E-mail:andrea030887@ukr.net болісним, комплаєнтним для пацієнта, пришвидшує настання клінічної ремісії.

\section{Список використаної літератури}

1. Бишарова А.С. (2012) Красный плоский лишай. Лечащий врач, 2: 24-28.

2. Мавров И.И., Болотная Л.А., Сербина И.М. (2007) Основы диагностики и лечения в дерматологии и венерологии. Факт, Харьков, 364-366 c.

3. Usatine R.P., Tinitigan M. (2011) Diagnosis and Treatment of Lichen Planus. Am. Fam. Physician, 84(1): 53-60.

4. К Качук Ю.В. (2014) Червоний плоский лишай. Навчальний посібник для самостійної роботи. Харків, 32 с.

5. Кацамбас А.Д., Лотти Т.М. (ред.) (2008) Плоский лишай. Европейское руководство по лечению дерматологических болезней. МЕДпресс-информ, Москва, 371-374 с.

6. Корсунская И.М., Невозинская 3.И., Захарова А.Б. и др. (2008) Опыт терапии красного плоского лишая препаратом Глутоксим. Рос. журн. кож. вен. бол., 1:44-46.

7. Романенко И.М., Кулага В.В., Афонин С.Л. (2006) Лечение кожных и венерических болезней. Руководство для врачей, в 2 т. Мед. информ. агентство, Москва.

8. ХэбифТ.П. (2008) Кожные болезни. Диагностика и лечение. МЕДпресс-информ, Москва, $672 \mathrm{c}$.

9. Молочков В.А., Прокофьев А.А., Бобров М.А., Переверзева 0.Э. (2011) Клинические особенности различных форм красного плоского лишая. Рос. журн. кож. вен. бол., 1: $30-36$.

\section{Experience of using the photosystem in the treatment of atypical forms of herpes zoster}

\section{M.M. Chemeris, A.A. Dekhtyarchuk}

Medical Center «Novoderm», Lviv

Abstract. Lichen ruber planus is one of the common diseases in dermatology. The incidence of this pathology has increased in recent decades. One of the highly effective methods of treatment today is the use of the phototherapy in the complex treatment of this pathology.

Key words: phototherapy, chronic dermatoses, herpes zoster, treatment of atypical forms of herpes zoster.

\section{Information about the authors:}

Chemeris Mariana M. - Candidate of Medical Sciences, dermatovenereologist, trichologist of the highest qualification category, Medical Center «Novoderm», Lviv.

Dekhtyarchuk Andriana A. — dermatovenereologist of the first qualification category, dermatooncologist, Medical Center «Novoderm», Lviv, Ukraine.

Address for correspondence:

Andriana Dekhtyarchuk

79026, Lviv, Academician Andrei Sakharov str., 82

E-mail: andrea030887@ukr.net 